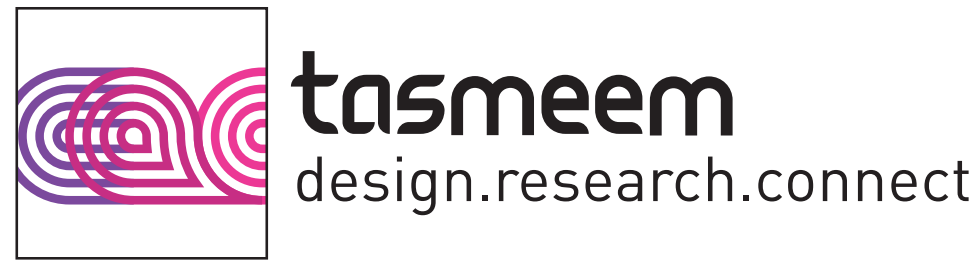

${ }^{1}$ UCL (University College London), UK ${ }^{2}$ Brunel University, UK

${ }^{3}$ The Open University, UK

^Email: clare.melhuish@ucl.ac.uk http://dx.doi.org/

10.5339/tasmeem.2014.4

Submitted: 5 March 2013 Accepted: 3 December 2013 (C) 2014 Melhuish, Degen, Rose, licensee Bloomsbury Qatar Foundation Journals. This is an open access article distributed under the terms of the Creative Commons Attribution license CC BY 4.0, which permits unrestricted use,

distribution and reproduction in any medium, provided the original work is properly cited.

Article

\section{Architectural atmospheres: affect and agency of mobile digital images in the material transformation of the urban landscape in Doha}

Clare Melhuish ${ }^{1, \star}$, Monica Degen ${ }^{2}$, Gillian Rose ${ }^{3}$

\section{ABSTRACT}

This paper explores how the hybrid making of Computer Generated Images on the Msheireb urban redevelopment project in Doha may be understood as a distributed and networked craft practice within the discipline of architecture and design, which is effecting the material transformation of the urban landscape and everyday urban life in Doha. We suggest that the evocation of 'atmosphere' through the digitalised production of these images mobilises ideas and aspirations for the construction of a 'new kind of place' and urban lifestyle, both as an imaginary and a reality, in the Islamic and Arab context, and that, as crafted images, CGIs should be seen as objects with social agency which are central to the construction of the project as a technological and social reality during its production phases as well as to its translation into the social reality of built form and urban life. 


\section{INTRODUCTION}

"CGIs, or three-dimensional images produced on the computer, are used in two different ways at the moment. One is to present the scheme to the outside world, to the client or the public, which is where 'atmosphere' is key. But also one's producing three-dimensional images for oneself, as it were, through the design process. And sometimes those images are the same and sometimes they're not"

(Msheireb project architect/masterplanner) $^{1}$

In this paper we explore some thoughts and findings on the way in which the making of digitallyproduced images, Computer Generated Images (CGIs), through hybridised processes (interdisciplinary and collaborative) of architectural design production, is contributing to the material transformation of the urban landscape in Doha, and the construction of notions of Qatari identity.

CGls are produced through a complex networked and reiterative process of production involving many different professional actors, and are in themselves 'hybrid' artefacts (or if you like, 'impure'2; or de-stabilising ${ }^{3}$ ), made up of many other kinds of images, pasted together and smoothed over, to mobilise an affective response in the viewer and ultimately a transformation of the built landscape. We suggest therefore that CGIs should be seen not just as seductive, pretty pictures, produced to please planners and entice the public, but also as carefully crafted artefacts, which have tangible substance and agency. They produce significant effects in terms of the reproduction of built environments as social settings, as demonstrated in the Msheireb urban redevelopment project in Doha, and therefore represent another, aesthetic and affective, dimension of the way in which, citing Thrift, "Software is writing cities"4. For that reason, they invite closer and more critical attention than they have so far been accorded by either social scientists interested in built space and social life, or by architects and architectural theorists interested in the implications of digital technology for architectural and urban design practice.

In particular, we suggest that the 'hybridised making' of CGIs on the Msheireb project explicitly mobilises notions of 'atmosphere' which have become current in architectural and urban design practice, in order to produce a commitment of political will and resources to the project through the construction of ideas of Qatari identity which are reproduced in the planned transformation of the urban landscape. So, drawing on the work of Latour and Gell5, CGIs may be seen not simply as representations, but as inscriptions, or crafted objects, which have affect and agency in the production of architecture and design. This agency derives from a process of making which engages many different actors and a wide range of technical and artistic expertise, in a complex network of distributed craft practice $^{6}$, and intensive interaction and negotiation. They are then, affective and effective inscriptions which result in the construction of facts ${ }^{7}$ : in this case, more than one hundred buildings and new public spaces in the centre of Doha, Qatar.

So, inspired by current debates around atmosphere and affect in human geography, Science and Technology Studies and Actor-Network-Theory in sociology, and concepts of art as agency from anthropology, we explore the following ideas:

1. That (some) CGIs explicitly mobilise notions of 'atmosphere' which have become current in architectural and urban design practice, in order to effect substantial shifts in political will and public attitudes to development, that allow for the transformation of urban landscapes on a large scale.

\footnotetext{
${ }^{1}$ Quote from author's interview with architect/masterplanner, Doha May 2012.

${ }^{2}$ Latour, B., We have never been modern (London: Simon and Schuster, 1993).

${ }^{3}$ Bhabha, H., Location of Culture (London, 1994).

4Thrift, N., 'The machine in the ghost: software writing cities' (paper presented at Hegemonies Conference, Lancaster University, Centre for Science Studies, 2001).

5Latour, B. and Woolgar, S., Laboratory life: the social construction of scientific facts. (London: Sage, 1979); Latour, B., 'Visualisation and cognition: drawing things together', in Representation in scientific practice, ed. M. Lynch and S. Woolgar (London, 1990), p 22; Gell, A., Art and agency: an anthropological theory. (Oxford: Clarendon Press/OUP, 1998); Gell, A., 'The technology of enchantment and the enchantement of technology', in Anthropology, art and aesthetics, ed J. Coote and A. Shelton (Oxford: OUP, 1992).

${ }^{6}$ Latour and Woolgar, Laboratory Life; Harvey, P., 'Between narrative and number: the case of ARUP's 3D digital city model', Cultural sociology 3, no. 2 (2009): 257-276.

${ }^{7}$ Latour and Woolgar, Laboratory Life.
} 
2. That (some) CGIs therefore have significant affect, or agency, which we can show through our

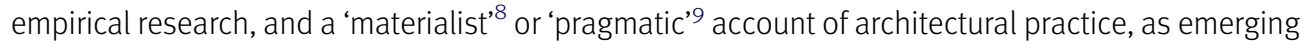
out of a collective process of production and work practices.

3. CGls are not simply then the product of certain social conditions ${ }^{10}$, but constitute an inscription of individual and collective identities, knowledge and values; allow for conscription of actors in a common venture; and lead to the objectification of a project in real life ${ }^{11}$. In that sense, CGls are not only representations, but actually have agency and become embedded in the construction of space, place and social life - through a powerful mobilisation and assemblage of people, skills and ideas.

\section{CGIS ASSEMBLING ACTORS AND LOCATIONS}

a. Methods

In order to produce this 'materialist' or 'pragmatic' account of the production and role of CGIs in the design process on this project, we employed a multi-sited ethnographic research method. As Schlecker and Hirsch have noted, the 'crisis of context' in ethnography means that the ethnographer must "abandon the study of compartmentalised local contexts and... follow the actor, around whom a network of alliances with other actors and things (actants) evolves"12. This observation seems especially pertinent to the operation of transnational architectural production across locations which we see today ${ }^{13}$, and in our case it has involved following CGIs themselves, at different stages of their production, around different sites in London, Liverpool, and Doha.

We have therefore spent time observing and describing people at work, taking photographs and video footage, and conducting 40 interviews in the offices of the eleven London and Liverpool-based architects and visualisers working on the Msheireb development - as well as in the offices of the client in Doha, on three separate fieldtrips in 2012 (Figure 1). In February 2012 we presented the aims and objectives of the research project in a seminar at the Msheireb Enrichment Centre to representatives from the client's office and Qatari academics, and invited their feedback; and in summer 2012 we organised a round-table discussion attended by seventeen of our research participants at the offices of the architect masterplanners, Allies and Morrison. We have amassed a considerable database of material documenting how people behave and interact with each other and with CGIs as visual artefacts in different work settings; how they use the tools and technologies of their trade to produce these mobile inscriptions; and how they perceive the process and purpose of their work in producing a vision of a new urban space and translating that into reality.

\section{b. Case study and actors}

The Msheireb project was originally known as Heart of Doha, describing its location at a site where "past, present and future meet, adjacent to the Emiri Diwan, close to Doha's cultural gem, Souk Wakif, and Doha's business centre in West Bay"14 This culturally significant and historic site in Qatar has been the focus of the combined efforts of a large number of participants from various parts of the world, intent on achieving its transformation within the context of a global agenda for urban regeneration. The project was initiated in 2005 by a Lebanese contractor (Orient Consultants), with a view to upgrading, or re-making, the environs of the Diwan al-Amiri, the seat of government, which were then populated by a large community of migrant workers from south India and Bangladesh, occupying rundown low-rise homes and business premises until wholesale demolition and clearance started in 2008/2009. The aim was to attract well-off Qatari citizens back to homes in a new sustainable, mixed-used development in the city centre, which they had largely abandoned in the 1970s;

\footnotetext{
${ }^{8}$ Latour, Visualisation and cognition, 22

'Yaneva, A, 'Reconnecting practice and meaning' (paper presented at RIBA Research Sympoisum, 'Changing Practices'. Royal Institute of British Architects, London, 2009).

${ }^{10}$ Brain, D. and Crane, D., 'Cultural production as ‘society in the making': architecture as an exemplar of the social construction of cultural artefacts', in The sociology of culture: emerging theoretical perspectives, ed. Crane, D.

${ }^{12}$ Schlecker and Hirsch, E., 'Incomplete knowledge: ethnography and the crisis of context in studies of media, science and technology', History of the human sciences 14, no. 1 (2001): p 78.

${ }^{13}$ Ren, X., Building globalisation: transnational architecture production in urban China (University of Chicago Press: Chicago/London, 2011).

${ }^{14}$ Dohaland brochure, 2010.
} 


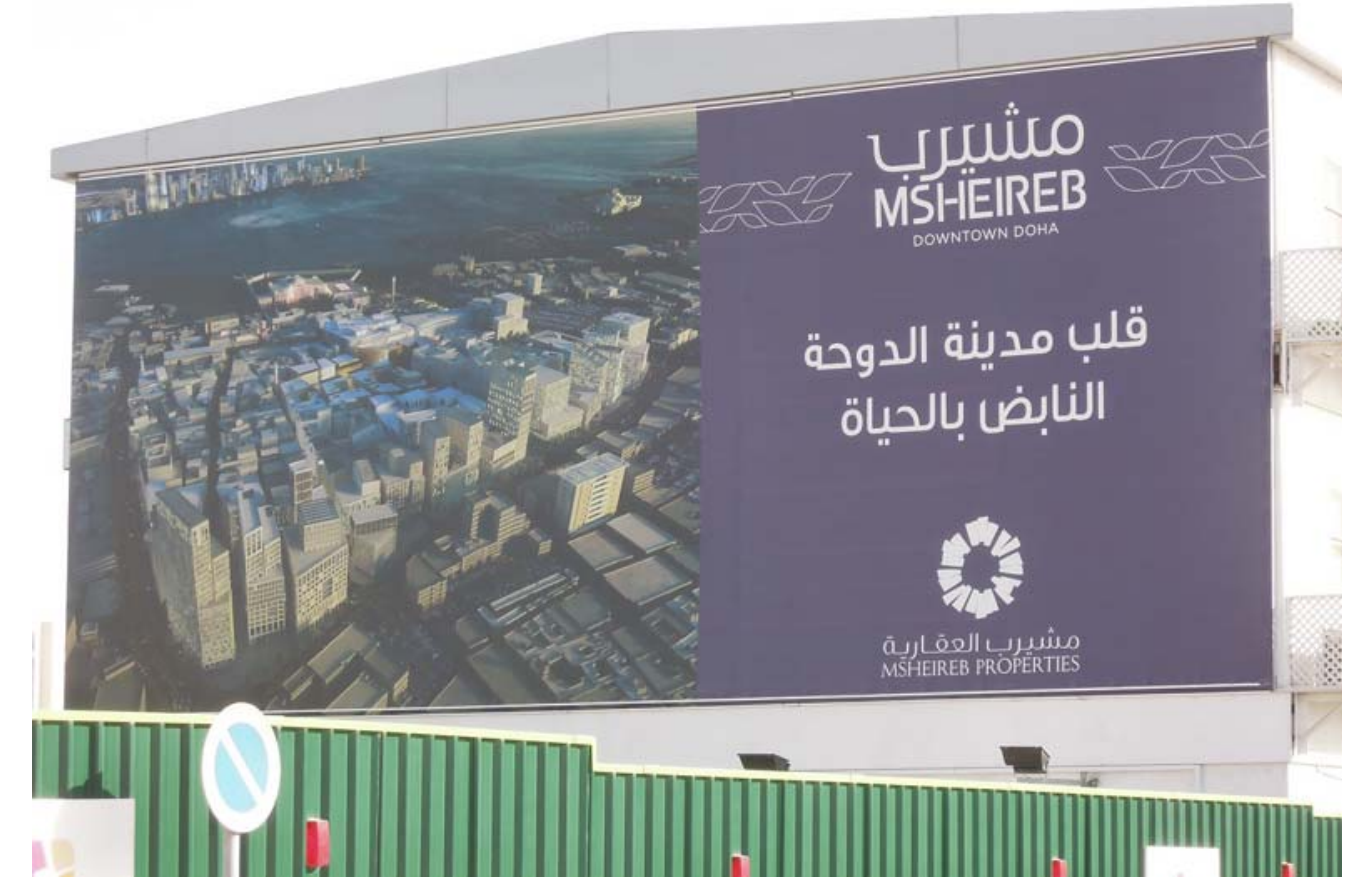

Figure 1. Site hoarding, Doha 2012.

supported by government compensation payments as it bought up city centre properties for proposed redevelopment at that time, they embraced a more comfortable and affluent lifestyle in suburban villas.

Salah Hawila invited the well-respected British multi-disciplinary firm Arups to develop a concept masterplan and mission statement for the project, and Arups in turn invited two further British firms, Edaw (now Aecom) and Davis Langdon to work with them. The project was taken up by the Qatar Foundation for Education, Science and Community Development (founded 1995), through its property development subsidiary, Dohaland, set up in 2007, and its chairperson Sheikha Mozah bint Nassr (Figure 2). She embraced Heart of Doha as a landmark scheme which could embody and promote concepts and practices of Qatari cultural identity, both in built form and in new urban living patterns, as a model for future development.

In 2007, a third British firm, the architects Allies and Morrison, was appointed on the basis of an architectural competition, to develop a coherent architectural language for the development, and a detailed masterplan. This involved a three-year long study by the architects (resulting in the design guideline document, The Seven Steps ${ }^{15}$ ), peer-reviewed by a panel of US academics, to "revive lost language of local architecture with a new blueprint for urban planning", as described in the same Dohaland brochure (2010). In 2008, Sheikha Mozah bint Nassr issued a video of the mission statement which built on this, framing the project as "a solution that will fill this void we have in our architecture... the first attempt to find what suits our identity"16 - in contrast to the modern, western-style development of West Bay and, implicitly, to the type of development seen in the neighbouring UAE states (Figure 3).

A further architectural competition for individual buildings on the site again resulted in the appointment of three British architectural practices (John McAslan and Partners, Adjaye Associates, Mossessian \& Partners). At the same time, a new director of development was put in place - an American architect, who had worked in Dubai with Emaar Properties. These appointments were followed by three big American firms as Executive Architects for the four phases of the project (Burns McDonnell, Gensler, and HOK), plus three further British Design Architects (Squire and Partners, Eric Parry Architects, MYAA) on Phases 2 and 3. In addition, an American landscape firm, Burtons, won

\footnotetext{
15“A New Architectural Language.” Accessed 2012. http://mdd.msheireb.com/home/architecturallanguage.aspx

${ }^{16}$ Mission statement video, Msheireb Enrichment Center, 2008
} 


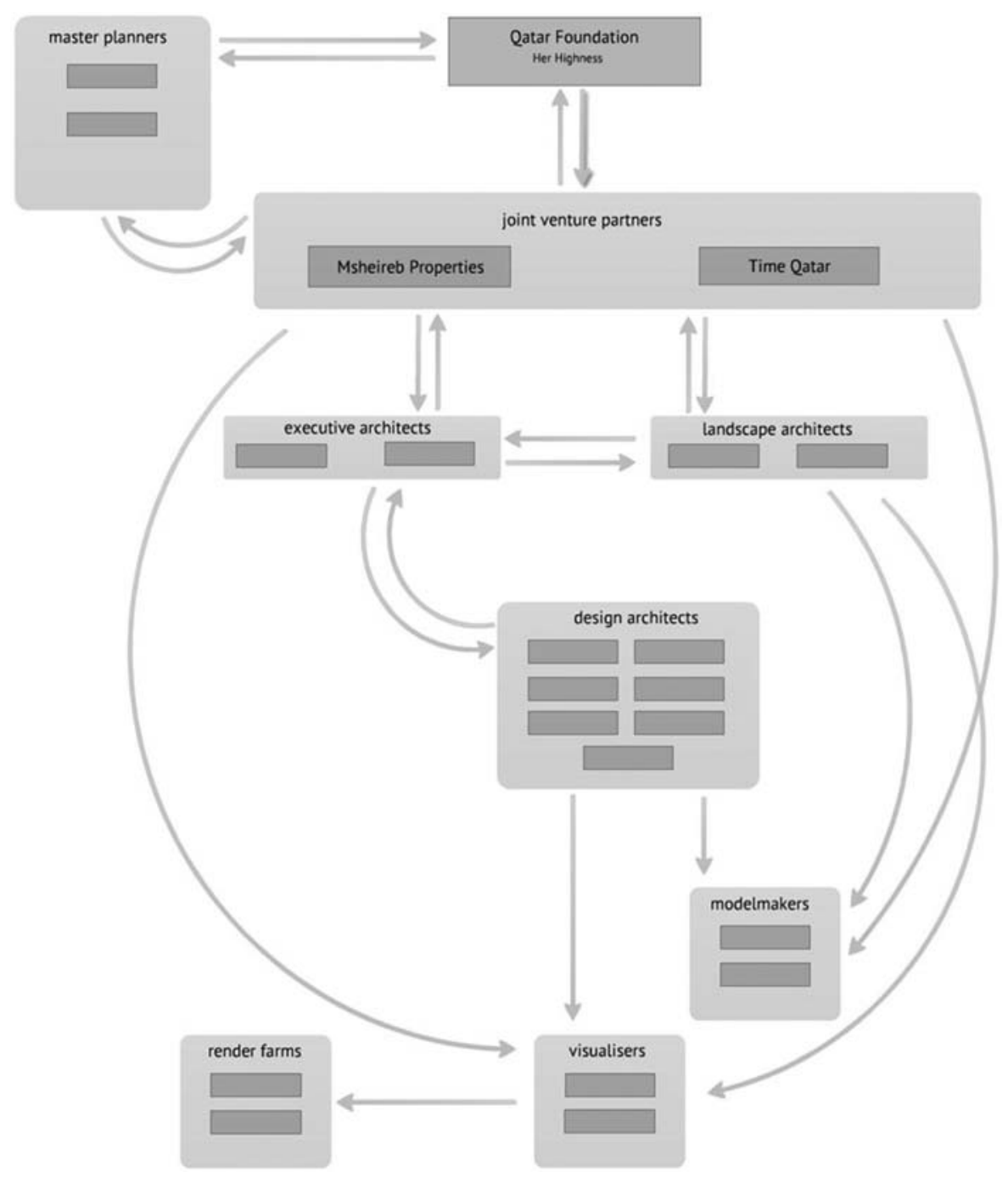

Figure 2. Network diagram showing circulation of images between the different actors on the development project.

the landscape design contract for the whole project, while sitewide visualisation was commissioned from Uniform, based in Liverpool, and Squint Opera in London. Other visualisers, including firms based in Germany and Portugal, were also commissioned to produce images of specific buildings by individual architects' practices; and more recently, marketing images have been commissioned by the client from firms in America, outsourcing to China, and Dubai. Finally, a US firm, Turner International Middle East (TIME), also based in Dubai, joined the project as joint venture partners with Dohaland subsequently re-branded Msheireb Properties: they describe their role as "helping the client to understand the process"17, as well as training Qatari employees as part of the planned 'Qatarisation' of the knowledge economy between now and the year 2030.

Hence the number of actors on the project, and their global distribution, has been wide-ranging. So too have their respective values, expertise and experience. These circumstances have been described by a project architect with A\&M as: "a three-way meeting of experience and expectation. One is the still point of Qatar, although it's not still because its defining itself, the other is the UK, with designers with more or less international experience but strong views about urbanism, and [thirdly] the people from Dubai, who are part of a great experiment of building things.... We had to sort of play the role as the orchestrator in terms of place-making because it was not familiar territory for anybody else"18 ${ }^{m a s t}$ but not least, is the

\footnotetext{
${ }^{17}$ Interview with author, Doha 2012

${ }^{18}$ Interview with author, Doha 2012
} 


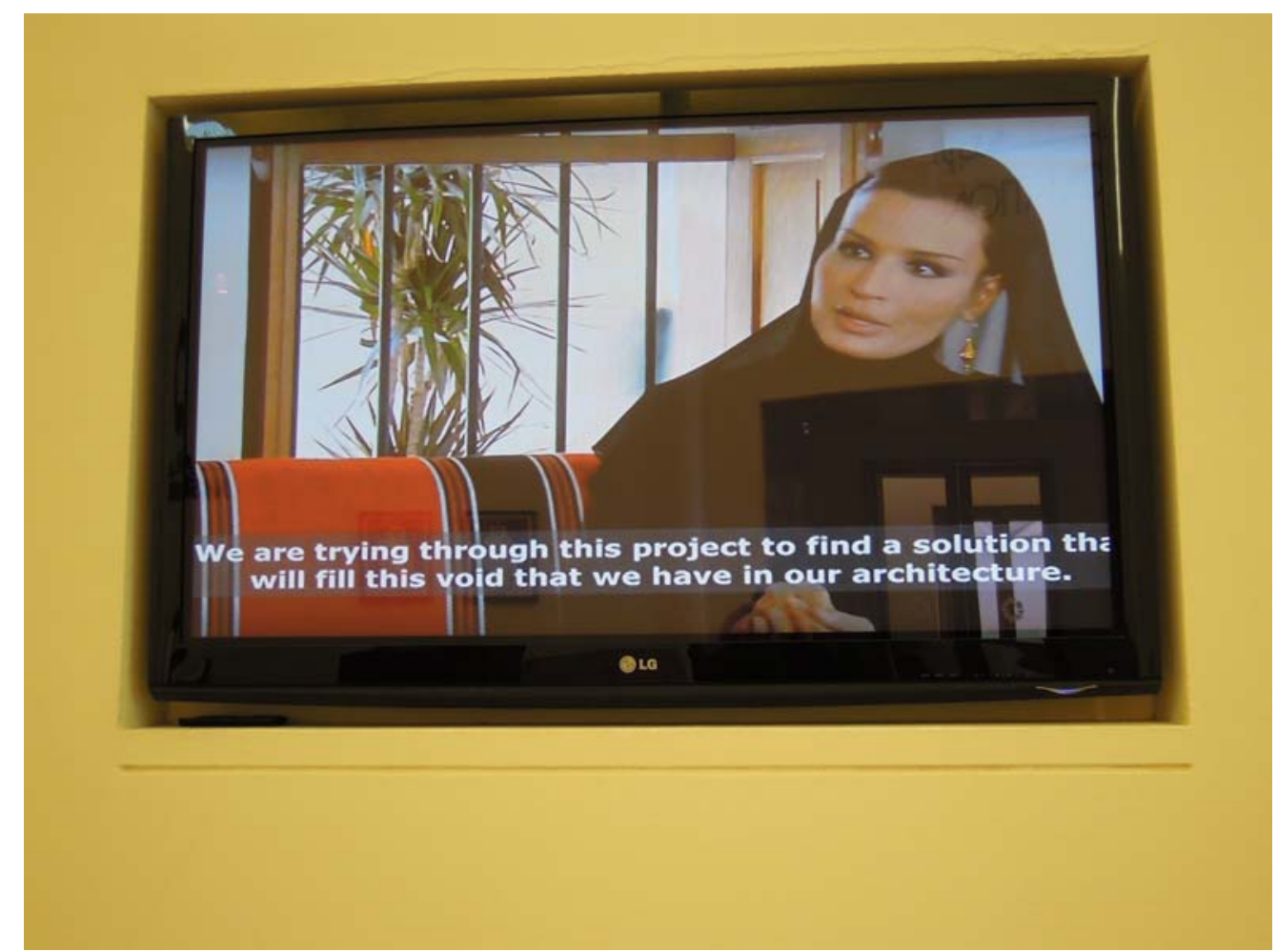

Figure 3. In 2008, Sheikha Mozah bint Nassr issued a video of the mission statement framing the project as "a solution that will fill this void we have in our architecture ... the first attempt to find what suits our identity".

Qatari public itself: quoting a Msheireb' marketing officer, the project is "about getting buy-in from Qataris". He says it's necessary to "get people to reminisce about the nostalgia they have" and, "A romanticised Msheireb is something that's happening.... When you show them the renders"19

\section{INVESTMENT IN (HYBRID) IMAGE PRODUCTION}

The last quote underlines the recognised agency of digital imagery, both still and animated, in this process of 'orchestration' - in assembling these disparate (and globally distributed) parties as 'allies' in the objectification of the project and its translation into built form. Images have been used intensively on the project from an early stage, and there has been a heavy investment in CGI production. From 2006 onwards, and quoting our architect respondent, imagery was being produced for three main reasons: "to help visualise the masterplan"; to "trigger the go-ahead for the project" from the Emir himself; and also, by Allies and Morrison, to help them understand the design guidelines, mix of uses, massing profile etc. - "to get running with the design language ... in the Seven Steps" 20 So images were being used as tools to work out what the development would look like, how it would be put together, and to convince the client to run with it - not simply as representations of particular building types, or even of a clear vision for the project. In fact it took several years to evolve an idea of the desired mix of Qatari and modern identity in built form, while working at an unprecedentedly fast pace.

It was really in 2009, when the project was launched to the public at the Qatari Real Estate Fair for the first time, that a film commissioned by Allies and Morrison from a visualisation company based in Portuga ${ }^{21}$ was deployed specifically to pull together material from the different architects and produce a narrative idea of what this new place would be like to live in - understood as a story, or an experience rather than a set of buildings. It was presented through the eyes of a little girl, and showed a set of key views through the site to convey a "sort of sense of the back street world of the Sikkas and the big open spaces... in the

\footnotetext{
${ }^{19}$ Interview with author, Doha 2012.

${ }^{20}$ Interview with author, London 2012.

${ }^{21}$ The visualisation company was Arqui 300 , based in Lisbon.
} 
meanwhile Dohaland had produced some marketing material for the papers.... So, if you like, the character and atmosphere of the scheme was finding its way into the public realm"22

This early visual material informed the development of the first Sitewide Development Guidelines into Master Development Standards, basically a compliance code enforced by the MDC team (Allies \& Morrison and Edaw), but one which contained "a combination of prescriptive diagrams and on the other hand mood boards" 23 . It is described by Allies \& Morrison's project architect as: "an anchoring of a set of possible outcomes of the character and atmosphere... that the designers then had to meet" ${ }^{24}$. All the architects were required by the client to submit their individual designs in digital visual format, at each stage of the design process (Concept, Schematic, Design Development), but the images were also vetted by the client's Architectural Language Advisor (originally a partner at Allies and Morrison), before they could be presented to the client's representatives at the all-important Design Review Boards in Doha where decisions were made (Figure 4).

The emphasis on imagery in this process has been described to us by one architect as "design by CGl", or "designing in the view" which has been unique to their experience ${ }^{25}$ Although the use of CGls for presentation and marketing is standard in the Gulf, and becoming the norm elsewhere, the design process itself on this project has been perceived as 'visually-led', which is not the way that architects usually work (logical spatial analysis). As one of our respondents put it, "the tools aren't really designed for us to use... They're not about spatial investigation, they're not about the things that architecture needs to be about, they're about producing a sexy image"26. Most architects do not have the skills, time or experience to produce high-quality visualisations themselves, but rely on visualisers either in-house or externally to realise their architectural ideas as images for them. This project meant that architects and visualisers had to work closely together to evolve and represent the design correctly, and also to produce affective visual images to engage and convince their audience. The images are created through a sequence of processes, from client briefing, to production of architectural drawings in AutoCAD software, and importation or creation of the three dimensional model in another software programme 3DS Max by a visualiser, who adds layers of material textures, lighting, and detail before rendering the model as a two dimensional image. Then it is transferred into Photoshop software, where possibly another visualiser adds more detailed visual effects, cutting and pasting from various sources, to produce a final image. Throughout this process, the images go back and forth between the different parties, under continuous review and revision, to achieve the best possible result.

Consequently, there was always a danger of designs being judged by the quality of the images, rather than on their own merits. One architect mentions how their design work on Phase 3 was "always criticised ... because the images were too abstract" ${ }^{\text {27 }}$. Design Review Boards, as we witnessed, became forums for intense and emotive interaction focused on images, where visual affect had a substantial influence on design development. CGls were also blown up to a large scale to create mock-ups at the client's offices where physical materials could be compared against their digital representation, and within the imagined context, as a basis for decision making (Figure 5).

The importance of these images was recognized in the later stages of production for presentation at a Special Design Review in January 2012 to the Sheikha, when detailed guidelines on composition, detail, and atmosphere of CGIs were drawn up by the Architectural Language Advisor, and these images were subsequently printed and hung in the client's offices in Doha, evaluated as artworks in themselves, not just tools for design and communication.

Thus the project has involved an unusually large investment in image production: it has been extremely labour and resource-intensive, generating thousands of CGIs along the way through a distributed network of technological expertise and craft practice. That investment demonstrates a recognition of the potency of CGls in effecting large-scale urban redevelopments; and a corresponding validation of the CGI in architectural production, which runs counter to many architects' lack of interest in digital images - as a distraction over which they have relatively little control. This suggests that CGIs

\footnotetext{
${ }^{22}$ See note 20.

${ }^{23} \mathrm{lbid}$.

${ }^{24}$ Ibid.

${ }^{25}$ Interview with author, London 2012.

${ }^{26}$ Msheireb project architect's contribution to round-table discussion for research participants held at offices of Allies and Morrison, London, June 2012.

${ }^{27}$ Interview with author, London 2012.
} 


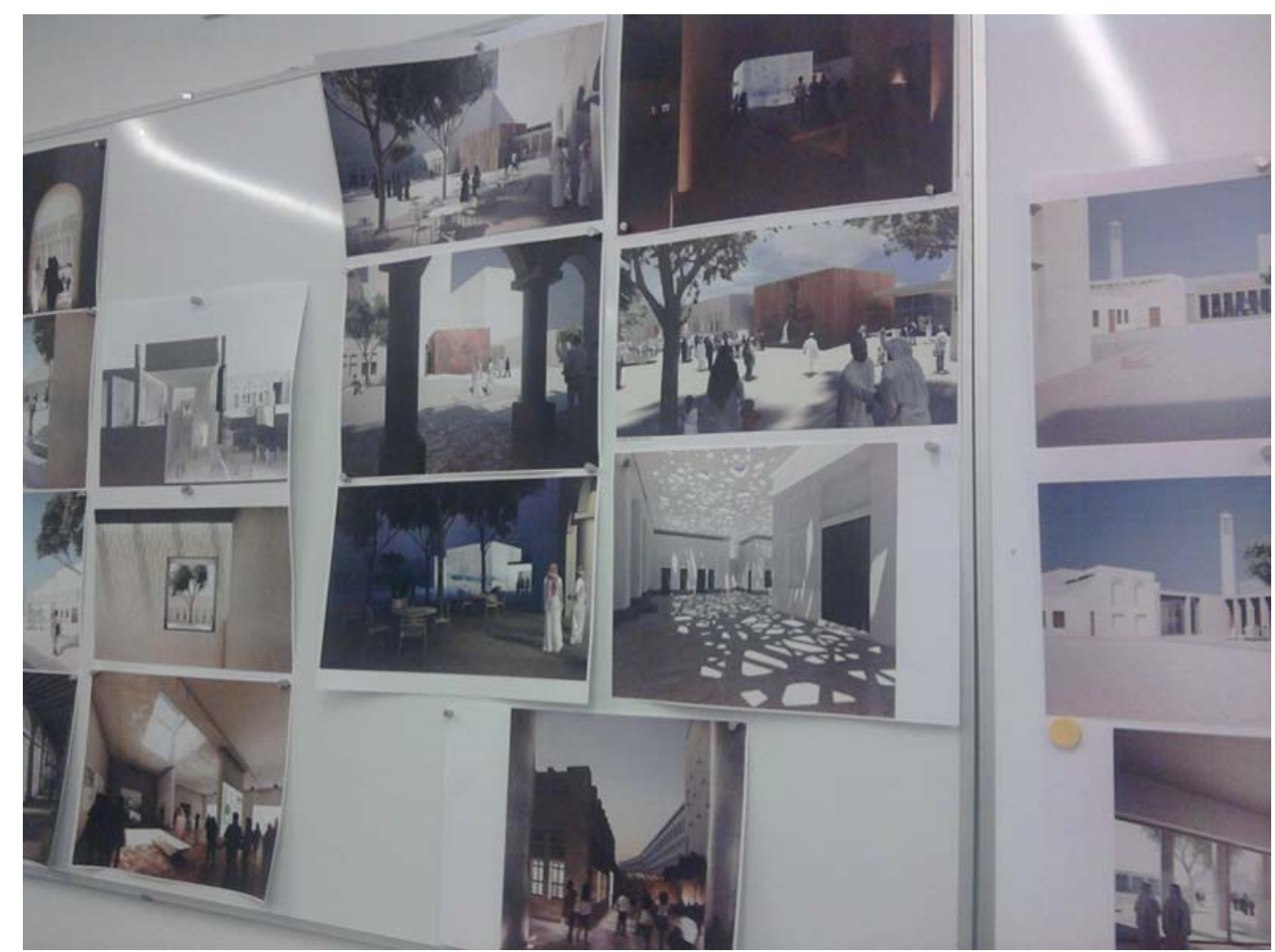

Figure 4. Architects were required by the client to submit their individual designs in digital visual format, at each stage of the design process.

are indeed worth closer scrutiny, as so-called actants in a network of alliances which is producing a "new kind of place" ${ }^{28}$ in Doha. We argue that the affect of the CGI image should be recognized as a combination of its material and visual qualities, in conjunction with the practices around which they are produced and deployed ${ }^{29}$ So let's now consider how CGIs, understood as crafted objects with tangible substance and agency of their own, mobilise notions of atmosphere and affect which are vital to this process, and become embedded in the construction of space, place and social life.

\section{ATMOSPHERE, AFFECT, AND CGI PRODUCTION}

\section{a. Gulf context - Msheireb as different}

At the beginning of our research project, we were interested in exploring the way in which notions of atmosphere and affect had entered the mainstream in architectural and urban design practice, and how the production of digital imagery was contributing both to branding and marketing within the context of the "experience economy" 30 and to the scripting of new urban experience. The Arab world provides an interesting context for this study. Although it has been the site of rapid urban development for some years, Elsheshtawy notes that modern Arab cities have been largely ignored in global city literature, or marginalised as little more than the result of rampant capital speculation and brand communication ${ }^{31}$. As Adham notes, "in the Gulf region ... an iconic war of hyper-signification is taking place in the realm of architecture" 32 as cities compete for business, tourists, consumers and capital. Doha, once branded by the Lonely Planet Guide travel series ${ }^{33}$ in the 1980 s the dullest city on earth, has been re-imaging itself

\footnotetext{
${ }^{28}$ Author's interview with partner at Allies and Morrison, London, 2011 (subsequenly Architectural Language Advisor to the client).

${ }^{29}$ Rose, G., Doing family photography: the domestic, the public and the politics of sentiment. (Farnham: Ashgate, 2010).

${ }^{30}$ Lonsway, B., Making leisure work: architecture and the experience economy (London: Routledge 2009).

${ }^{31}$ Elsheshtawy, Y, 'The great divide: struggling and emerging cities in the Arab world', in The Evolving Arab City, ed. Elsheshtawy, Y. (London: Routledge, 2008), 1-26.

${ }^{32}$ Adham, K., 'Rediscovering the island: Doha's urbanity from pearls to spectacle' in The Evolving Arab City, ed. Elsheshtawy, Y. (London: Routledge, 2008), 244.

${ }^{33}$ The Lonely Planet Guide travel book series, as mentioned by Adham, (ibid).
} 


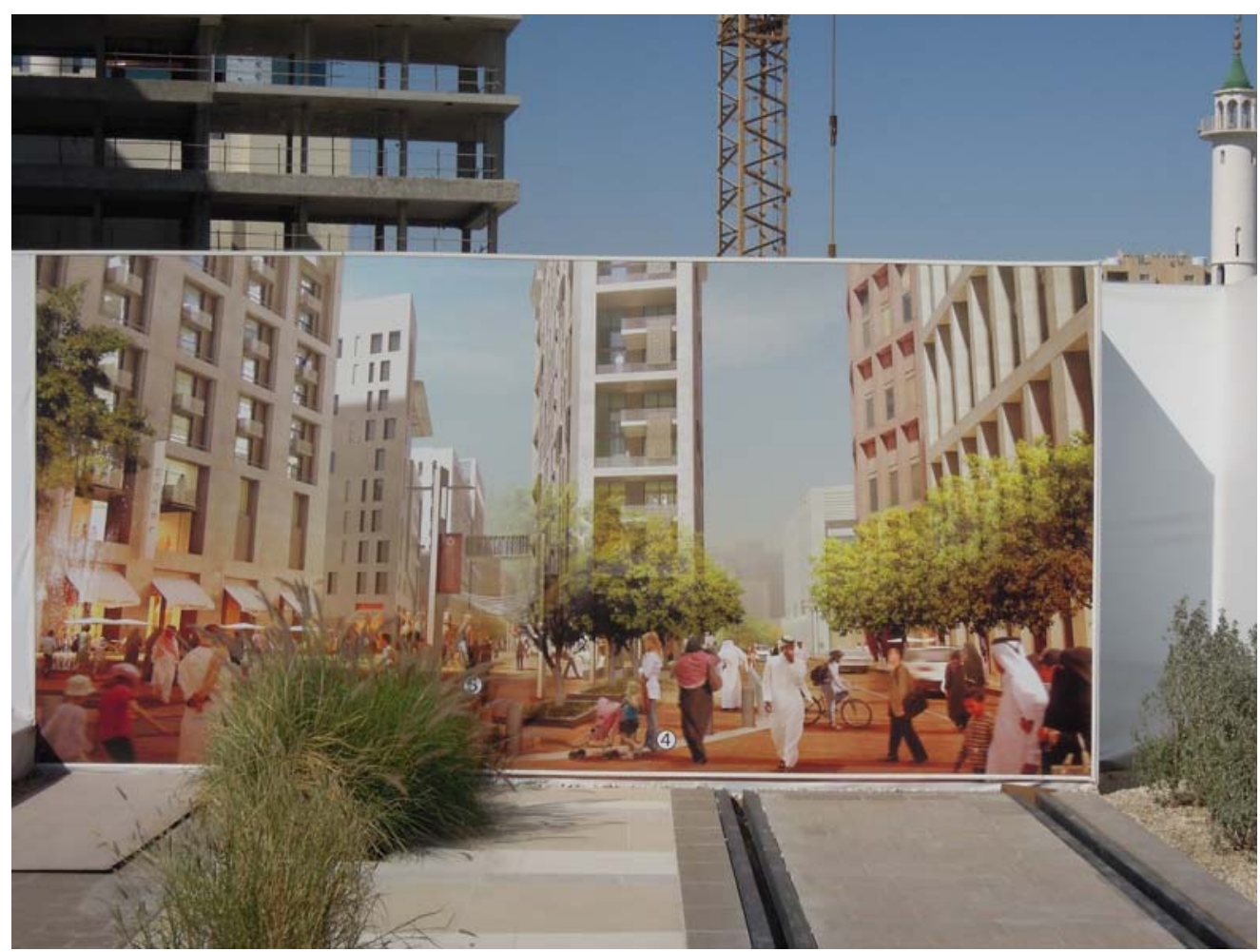

Figure 5. CGIs were also blown up to a large scale to create mock-ups at the client's offices where physical materials could be compared against their digital representation, and within the imagined context, as a basis for decision making.

since the 1970 and 1980 s, but without a clear sense of its own identity, and he asks, "One may wonder ... which city constitutes the image-model for Doha. Is it Dubai? Is it Paris? Or is it an assortment of hybrid spaces which have neither specific geographic locale nor time frame?"34

This question is fundamental to the Msheireb initiative: it is all about establishing a new model for development in Doha which will set it apart from its neighbours and garner respect on an international platform, beyond the Gulf. Mobilising an idea of identity, memory, and urban 'atmosphere' has been at the core of the initiative, as it has been shaped by its British masterplanners. But at the start no one really knew how this new model was going to be achieved: "this was a project that had a whole new set of ingredients. And was also not even common in the region. Whereas, experience out here is more about bigger and better iconic Dubai" ${ }^{35}$. The Msheireb masterplan is unusual in the Gulf, in that it comprises large residential, office, retail, civic, and cultural components integrated with social amenities, mosques, and public spaces designed to prioritise pedestrians in a car-dominated city. The design of the individual buildings has been strictly controlled by an overall design framework, to create a coherent whole, integrated with the surrounding urban fabric. It is also intended to be sustainable, making use of natural cooling methods to create habitable outdoor and indoor spaces for much of the year, even though it also incorporates an enormous multi-storey underground carpark. The principal challenge was to convince client, public and consultants alike that such a project could work and flourish in this part of the world, where private and public life are strictly segregated ${ }^{36}$, mall culture is prevalent, and most people shun outdoor activities. CGIs have therefore has been heavily used both to work out the design parameters of the development, and to generate an evocative idea or feeling of a new kind of place.

\footnotetext{
${ }^{34}$ Ibid, 252.
}

${ }^{35}$ Author's interview with Msheireb project architect, Doha 2012.

${ }^{36}$ as Mitchell points out, the concept of 'the public' does not yet exist in Qatar, only 'other families': "When societies are an amalgam of families, as they are in the Middle East, the idea of a public in which each man participates quite independent of his familial location cannot easily take hold." Mitchell, J., Toqueville in Arabia (Chicago and London, 2013) 69. 


\section{b. Functional vs. affective roles of images}

At one level, it was vital for the architects to produce effective imagery to communicate with the client body, because it involved a hierarchy of different people, not all of whom could understand architectural drawings well. They therefore relied upon 3D images to generate design decisions, sign-offs of consecutive work stages, and payment of fees. But at another level, images had to be 'affective', to mobilise belief in the project, not just as another real estate development, but as a flagship for distinct ideas of Qatari culture and heritage. As a Msheireb marketing manager pointed out, the project required an enormous amount of political will and commitment, and the distribution of the images as they have been produced, in different forms and places - books, billboards, websites, property fairs, postcards, and mock-ups on site - has played an important role in drawing people in to the 'feeling' of the new reality which they both depict as built form and evoke as a social imaginary: " ... it's this reinvention, the project is a new urban quarter, and selling that whole is about how you present it to the public because all the hoardings, the movie, are about dreaming into this new place" ${ }^{37}$.

Seductive architectural marketing imagery is common in the Gulf and elsewhere, but scholarly attention ${ }^{38}$, has tended to focus on the superficiality and glamour of what such images represent, and their screening function in relation to the tough social realities of Arab urban development. By contrast, we want to explore the way in which the Msheireb imagery is being produced to create a specifically affective Qatari identity and reworking of Doha's urbanity as atmospheric, not simply as a cosmopolitan consumer paradise, which is different from other regional developments - although nobody will know for some time what the final outcome will actually be in terms of built form.

So how has this idea of atmosphere been recognised, defined, mobilised and produced? And how are these images different? Cultural geographers such as Thrift and Amin have forwarded and developed notions of non-representationalist space which is lived and felt, through movement, the senses, and relationality, rather than intellectually grasped ${ }^{39}$. Latham and McCormack propose that "to speak of the affective materiality of the urban is to speak of the intensity of the relations in and through which it consists" ${ }^{40}$, and such ideas have been explored within a phenomenological strand of architectural thinking ${ }^{41}$. On the Msheireb project, a conscious effort to mobilise notions of atmosphere and affect through digital imagery has been made by one individual actor in particular, the Architectural Language Advisor to the client, who has a long-standing interest in architectural and photographic imagery. He has been responsible for art directing and co-ordinating much of the output from the various architectural and visualisation studios. Not all the different architectural and visualisation offices have found it easy to "become part of a collective" as it has been described ${ }^{42}$, in a competitive world where individual authorship and brand identity is highly valued; but at the same time the value of the role is recognized: "on projects like Msheireb, ... you're setting up this dream world, which is what [he] is very good at - he can evoke things by the way he directs or works with the person doing the visualisation, without actually designing anything at all"'43

The Architectural Language Advisor has brought CGIs to the centre of the architectural production process, emphasising the role of low camera angle, foreground detail ("entourage", as he calls it ${ }^{44}$ ), hazy light quality, material textures, "memorable moments", and traces of social life in the composition of the images, to evoke a holistic sensory experience of space as a social

\footnotetext{
${ }^{37}$ Msheireb project architect's contribution to round-table discussion, London 2012.

${ }^{38}$ for example, Jackson, Mark S., and Dora, V. della, 'From landscaping to 'terraforming'?: Gulf mega-projects, cartographic visions and urban imaginaries', in Landscapes, identities and development, ed. Agnew, J., Roca, Z., and Claval, P. (Farnham: Ashgate, 2011).

${ }^{39} \mathrm{Amin}, \mathrm{A}$ and N Thrift, Cities: Re-imagining the Urban (Oxford, 2002); Thrift, N., Non-representational theory: space, politics, affect (London: Routledge, 2007).

${ }^{40}$ Latham, A., and McCormack, D., 'Moving cities: rethinking the materialities of geographies', Progress in Human Geography 28 (2004): 706.

${ }^{41}$ as developed at the School of Architecture at the University of Cambridge, UK, during the 1990 on under Dalibor Vesely and Peter Carl, and more recently in the work and writings of architects such as Pallasmaa and Zumthor. Pallasmaa, J., The thinking hand: existential and embodied Wisdom in architecture (Chichester: Wiley, 2009); Pallasmaa, J., Eyes of the skin: architecture of the senses (Chichester: Wiley, 2005); Zumthor, P., Atmospheres: Architectural Environments - Surrounding Objects (Berlin: Birkhauser, 2006).

${ }^{42}$ Author's interview with Msheireb project architect, London 2011.

${ }^{43}$ Msheireb project archiect's contribution to round-table discussion, London 2012.

${ }^{44}$ Msheireb project Architectural Language Advisor, “Seven Golden Rules for CGI making” (unpublished document, 2011).
} 
(not just architectural) process ${ }^{45}$. The images are focused on producing a sense of being immersed in zthe space, not just looking at it as a spectator: as an evocation of lived, haptic experience, or the 'sidewalk ballet' described by Jane Jacobs in $1961^{46}$, with an emphasis on following pedestrian routes through the site, it is an anti-spectacular approach ${ }^{47}$. Although mediated by software code and pixels, the ALA promotes graininess, "less pixels!" ${ }^{48}$, resulting in a palpable difference from the more mainstream CGI culture of glossy, sharp-edged, over-focused 'hero shots'. "Can I 'hear' the rustling in the trees, the babbling of fountains, the bell of the tram?" he writes in his Seven Golden Rules for CGI Views ${ }^{49}$; "Skies (what is a Qatari sky?) - generally quite featureless, strongly graded down to the Horizon, it is almost thick, humid ....?" His list of "Words" 50 to evoke the qualities of development as place includes "memories, heart, rootedness, timelessness, family, shade ... seasonal ... cherish ... connection, threshold". He compares architectural design to stage-set design, but emphasises the need for authenticity based in thorough local research, combined with observation of real-life experience in Qatar, and an understanding of Qatari history and culture. Memory, nostalgia and yearning for past traditions of social interaction and identity become the anchor for future modernisation and development; and the views themselves are carefully identified by the ALA to show smaller, more intimate spaces, with glimpses of other spaces beyond, as stages for human activity.

These suggestions and directives are delivered through a combination of briefing (RfPs), verbal critique in DRBs, and mark-up of electronic and printed copies, through which 'atmospheric' images are materialised. It generates a constant back-and-forth flow of comments, revisions, and updates, shared in meetings, by email, or Google Docs, among architects, visualisers, consultants and client representatives, and inscribed (or not, as the case may be) through reiterative software operations by different individuals, interfaces between AutoCAD, 3DS Max, and Photoshop softwares, lengthy rendering processes, and expensive printing - not to mention the raiding of internet-based image libraries, and occasional photoshoots. In common with other types of craftsmen, the visualisers work with the choices that the software materials offer, making decisions in specific situations, within the framework of the brief they are given ${ }^{51}$; little by little, interests, social relations, institutional demands, structural conditions are transcribed into the material form of an artefact, the digital or printed copy of the $\mathrm{CG}^{52}$.

The extent of the production process behind these images, and the enormous number of large digital files which it generates, implicating innumerable computers, printers, workers, and decisions, belies the apparent lightness of the digital medium, and reminds us of the materiality of the network through which digital images circulate ${ }^{53}$, and the extent to which it is governed by social relations and performances played out in real, physical locations, over phone lines, and through emailed texts. Any sense of individual authorship is subsumed by conscription into a collective project which is vital to its successful implementation; it typifies digital processes of 'anthological' communication, as described by Doueihi ${ }^{54}$. During the process, through each modification and added layer of texture, colour, light and detail, and passed from one worker to the next, it is the CGIs themselves which grow in affective presence and become the centre of attention - methodically built up by the people implicated in their production, from ghostly chalky-white massing studies to detailed, evocative images. They emerge as art objects which mediate social relations in and between offices ${ }^{55}$.

The movement of the inscribed images from London to Doha, and their translation into the cultural context of the DRB - the interface between the professional teams and the client's team - is the moment when their agency in mobilising the next stage of the project or not is revealed.

\footnotetext{
${ }^{45}$ Degen, M., Sensing cities: regenerating public life in Barcelona and Manchester (London: Routledge, 2008).

${ }^{46}$ Jacobs, J., The death and life of great American cities (London, 1992).

${ }^{47}$ Debord, G., Society of the spectacle (London: Verso, 1990); Jameson, F., Postmodernism or the cultural logic of late capitalism (London, 1991); Virilio, P, Open sky (London: Verso 1997).

${ }_{48}^{8}$ author's interview with ALA Doha 2012.

49 ibid.

${ }^{50}$ Msheireb project Architectual Language Advisor, “'Words' 28.02.12” (unpublished document, 2012).

${ }^{51}$ Harvey, Between Narrative and Number.

${ }^{52}$ Bourdieu, P., Reproduction in education, society and culture (London: Sage, 1990).

${ }^{53}$ Latour, B. 'Networks, Societies, Spheres: Reflections of an Actor-Network Theorist', International Journal of Communication 5, (2011): 802.

${ }^{54}$ Doueihi, M., Digital cultures (Harvard University Press, 2011).

${ }^{55} \mathrm{Gell}, \mathrm{A}$., Art and agency: an anthropological theory (Oxford: Clarendon Press/OUP, 1998).
} 


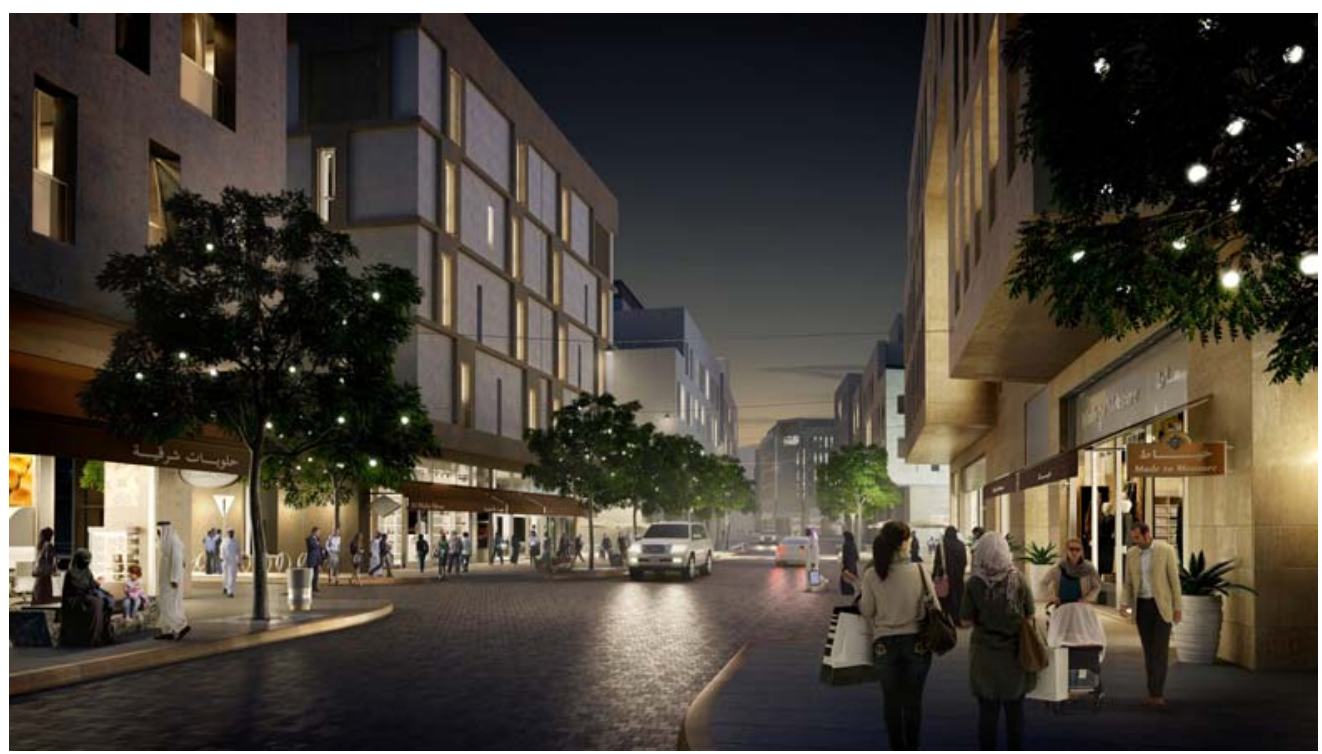

Figure 6. CGI which has been updated many times in London.

These meetings involve a mix of objective discussion around technological and structural design issues, and highly subjective responses to the look and feel of an image which highlights linguistic nuances across both professional and cultural divides. In a DRB (November 2012), on 'integrated Public Realm Design', discussion moved from waste management to the desired atmosphere of the central shopping street. All eyes are trained on a CGI which has been updated many times in London (Figure 6). In its latest incarnation it includes new misty lighting effects, and a selection of new people photographed in a specially-organised photoshoot in London. Concern has been expressed that there's "not enough going on" 56 in the street at the moment, it needs more programming, maybe background music, a light show... The ALA is presenting the case for an informally-managed public space that evokes the spirit and diversity of the old street which it replaces - "it's got a drumbeat, a tune, but each person doing their own thing". It's "a happy anarchy, a jazzy harmony". Someone asks, "are these architectural terms?! They're not project management terms!" The client responds, "this is a living thing, it's got to change... we cannot imagine what it's going to look like unless we test it." ${ }^{\text {I }}$ Afterwards, the ALA suggests the image in question has not completely conveyed the feeling he is after: "the conjuring of atmosphere.. they don't seem to engage with the subject, like the front cover of a magazine, which is what every view ought to be. ${ }^{58}$ Yet another revision seems likely before the next review.

\section{CONCLUSION: AGENCY AND EFFECTS OF DIGITAL IMAGES ON MATERIAL LANDSCAPE AND EXPERIENCE OF SPACE (WHY CGIS ARE WORTH LOOKING AT)}

On the one hand, CGls are valued as design tools and for their communicative potential to describe or simulate a future built reality with photographic accuracy, which is visually accessible and can be easily understood by a client or member of the public. But on the other hand, it is recognized that they have agency invested in their evocation of an affective atmosphere. Their portrayal of small-scale, intimate spaces and routes between buildings, contrasting textures, light and shade, and detailed human interactions, convey a haptic and sensory experience of space - in contrast to the glossy hero shots of many CGIs - and stimulates a perceptual response in the audience to the idea of a new place. This in turn represents 'action in potential', as conceived by Bergson"59; as Grosz elaborates: "perception propels us towards the real, toward space, objects, matter, the future,60 - in this case, the future of Doha.

\footnotetext{
${ }^{56}$ Quotes from design review board participants, Doha 2012

57ibid.

${ }^{58}$ Msheireb project Architectural Language Advisor in conversation with author, as above.

${ }^{59}$ Bergson, H., The creative mind: an introduction to metaphysics (New York, 2002).

${ }^{60} \mathrm{Grosz}$, E., Architecture from the outside: essays on virtual and real space (Cambridge Mass; London: MIT Press, 2001) $120-121$.
} 
The challenge of translating the Msheireb project into reality should not be underestimated, and affective CGIs are central to this process. A key issue is the negotiation of cultural difference between producers invited in because of their expertise in design and place-making, and client/audience with the authority to implement the project. Most of the producers have little idea of Qatari identity, and are dependent on art direction from the ALA to build up an imagined view of modern Qatari life within a broadly cosmopolitan framework, using a collage of cultural references imported from different sources. But the evocation of unfolding, small-scale spatial experience and human interactions in atmospheric CGIs creates a palette of common sensory perception and response which helps to mediate cultural difference. It also breaks down and humanises the sheer scale and scope of the development, which embodies that 'spatial restructuring and rescaling of governance', enabled by the operation of software and networked technology, described by Sheller ${ }^{61}$. The transformation of the urban landscape at Msheireb exemplifies the way in which "infrastructure and landscape, 'infrascapes', have increasingly become the new design scale for architecture”, as noted by Hoete ${ }^{62}$, demanding a massive co-ordination of resources, expertise, collective belief, and political will. Evocative CGls are a product of the social and cultural conditions which produce 'infrascapes', but they also have agency in mediating that scale and impersonality, through intimate views, story-telling and urban atmosphere, which re-frame radical urban transformation as a more graspable and manageable concept - 'felt' place - and so become effective in its materialisation.

Furthermore, they 'democratise' the design process, as one visualiser puts it, by creating an accessible and participatory platform of communication (the 'doughnut effect', with a hole at the centre where the architect used to be ${ }^{63}$ ). Harvey has described how a 3D digital model used by Arups in the UK is effective because of the way it contrasts realist descriptive stability with open-ended potentiality or multiplicity, which invites people to participate in what it depicts ${ }^{64}$. Likewise, CGIs are realist and descriptive, but also mutable, open to constant revision and update. Although some architects also suggested CGIs could limit negotiation by looking too real, fixed and finished in some cases, it has been evident on the Msheireb project that CGIs opened up a powerful field of negotiable potentiality among diverse actors across locations and across cultures. Thus, as art objects which are also technical, they serve both "to build, maintain and stabilize the structure of links between diverse actants" $" 65$ within a network of material, technological and social relations, and, through their affective presence, to provide a stimulus towards action. In this sense then, CGIs may be seen as central both to the construction of the project as a technological and social reality during its production phases, and to its translation into the new social reality of built form and urban life in Doha in the coming years.

\section{BIBLIOGRAPHY}

Adham K. Rediscovering the island: Doha's urbanity from pearls to spectacle. In: Elsheshtawy Y, ed. The Evolving Arab City. London: Routledge; 2008:218-257.

Akrich M. The description of technical objects. In: Bijker WE, Law J, eds. Shaping Technology/Building Society: Studies in Sociotechnical Change. Cambridge MA: MIT Press; 1992:205-224.

Amin A, Thrift N. Cities: Re-imagining the Urban. Cambridge: Polity; 2002.

Bergson H. The Creative Mind: An Introduction to Metaphysics. New York: Citadel Press; 2002 [1946].

Bhabha H. Location of Culture. London: Verso; 1994.

Brain D, Crane D. Cultural production as 'society in the making': architecture as an exemplar of the social construction of cultural artefacts. In: Crane D, ed. The Sociology of Culture: Emerging Theoretical Perspectives. Oxford 1994:191-220. Bourdieu P. Reproduction in Education, Society and Culture. London: Sage; 1990.

Debord G. Society of the Spectacle. London: Verso; 1990 [1967].

Degen M. Sensing Cities: Regenerating Public Life in Barcelona and Manchester. London: Routledge; 2008.

Doueihi M. Digital Cultures. Cambridge MA: Harvard University Press; 2011.

Elsheshtawy Y, ed. The Evolving Arab City: Tradition, Modernity and Urban Development. London: Routledge; 2008.

Gell A. Art and Agency: An Anthropological Theory. Oxford: Clarendon Press/OUP; 1998.

Gell A. The technology of enchantment and the enchantment of technology. In: Coote J, Shelton A, eds. Anthropology, Art and Aesthetics. Oxford: OUP; 1992.

\footnotetext{
${ }^{61}$ Sheller, M, 'Infrastructures of the imagined island: software, mobilities, and the architecture of Caribbean paradise', Environment and planning A 41(2009): 1392.

${ }^{62}$ Hoete, A., "Zaha Hadid: automobility and architecture" in Reader on the aesthetics of mobility, ed. Hoete, A. (London: Black Dog 2003), 146, cited in Sheller, Infrastructures of the Imagined Island, 1392.

${ }^{63}$ Concept described by Msheireb project visualiser in conversation with author, London 2012.

${ }^{64}$ Harvey, Between Narrative and Number.

${ }^{65}$ Akrich, M.,'The description of technical objects', in Shaping technology/building society: studies in sociotechnical change, ed. Bijker, W.E., and Law, J. (Cambridge MA, 1992), 205-224.
} 
Grosz E. Architecture from the Outside: Essays on Virtual and Real Space. Cambridge MA; London: MIT Press; 2001. Harvey P. Between narrative and number: the case of ARUP's 3D digital city model. Cult Sociol. 2009;3(2):257-276. Hoete A. Zaha Hadid: automobility and architecture. In: Hoete A, ed. Reader on the Aesthetics of Mobility. London: Black Dog; 2003.

Jackson MS, Della Dora V. From landscaping to 'terraforming'?: Gulf mega-projects, cartographic visions and urban imaginaries. In: Agnew J, Roca Z, Claval P, eds. Landscapes, Identities and Development. Farnham: Ashgate; 2011. Jacobs J. The Death and Life of Great American Cities. London: Vintage; 1992 [1961].

Jameson F. Postmodernism or the Cultural Logic of Late Capitalism. London: Verso; 1991.

Latham A, McCormack D. Moving cities: rethinking the materialities of geographies. Prog Hum Geog. 2004;28:701-724. Latour B. Visualisation and cognition: drawing things together. In: Lynch M, Woolgar S, eds. Representation in Scientific

Practice. London: MIT Press; 1990.

Latour B. We Have Never Been Modern. London: Simon and Schuster; 1993 [1991].

Latour B, Woolgar S. Laboratory Life: The Social Construction of Scientific Facts. London: Sage; 1979.

Latour B. Networks, societies, spheres: reflections of an actor-network theorist. Int J Commun. 2011;5(19328036):796-810.

Lonsway B. Making Leisure Work: Architecture and the Experience Economy. London: Routledge; 2009.

Mitchell J. Toqueville in Arabia. Chicago and London: University of Chicago Press; 2013.

Pallasmaa J. The Thinking Hand: Existential and Embodied Wisdom in Architecture. Chichester: Wiley; 2009.

Pallasmaa J. Eyes of the Skin: Architecture of the Senses. Chichester: Wiley; 2005.

Ren X. Building Globalisation: Transnational Architecture Production in Urban China. Chicago/London: University of Chicago Press; 2011.

Rose G. Doing Family Photography: The Domestic, The Public and The Politics of Sentiment. Farnham: Ashgate; 2010.

Schlecker and Hirsch E. Incomplete knowledge: ethnography and the crisis of context in studies of media, science and technology. Hist Hum Sci. 2001;14(1):69-87.

Sheller M. Infrastructures of the imagined island: software, mobilities, and the architecture of Caribbean paradise. Environ Plan A. 2009;41:1386-1404.

Thrift N. The machine in the ghost: software writing cities. Paper presented at Hegemonies Conference, Lancaster University (Centre for Science Studies), 2001.

Thrift N. Non-representational Theory. Space, Politics, Affect. London and New York: Routledge; 2007.

Virilio P. Open Sky. London: Verso; 1997.

Yaneva A. Reconnecting Practice and Meaning. Paper 05 presented in RIBA Research Sympoisum, Changing Practices. Royal Institute of British Architects, London, 2009.

Zumthor P. Atmospheres: Architectural Environments - Surrounding Objects. Berlin: Birkhauser; 2006. 